УДК 347

DOI https://doi.org/10.32849/2663-5313/2020.4.02

\title{
Катерина Валігура,
}

аспірант кафедри цивільного права

юридичного факультету

Київського начіонального університету імені Тараса Шевченка

\section{ПРИНЦИП ДОБРОСОВІСНОСТІ ЯК КАТЕГОРІЯ ЦИВІЛЬНОГО ПРАВА}

Стаття присвячена дослідженню основних форм вираження принципу добросовісності иивільного права та міжнародного приватного права. Актуальність дослідження визначається, зокрема, гострою потребою в правовому визначенні принципів добросовісності в Цивільному кодексі. Інтерес до наукового та практичного вивчення иих принципів у иивільному праві викликаний різноманітними причинами, зокрема тим, що законодавещь не розкриває зміст иих приниипів у Цивільному кодексі. Доктрина міжнародного иивільного права також не має положень, які описують та характеризують специфіку застосування приниипу добросовісності.

У прочесі роботи було проведено порівняльний аналіз приниипу добросовісності у Стародавньому Римі та його сучасний стан, виявлення загальних та особливих характеристик. Роль принципу добросовісності в правовому порядку трактується через функиї та чінності. Коли застосовується приниип добросовісності, його зміст має бути визначений відповідно до конституиійних иінностей, иінностей звичайних законів та стандартів колективних иіннісних переконань.

Принципи права визначають загальну спрямованість, високу якість та ефективність правотворчої та практичної практики в будь-якому иивілізованому суспільстві. Ось чому таке велике значення має об'єктивне та всебічне вивчення иього явища як на загальнотеоретичному, так $i$ на галузевому рівні юриспрудениіі.

Для вирішення поставлених у роботі завдань добросовісність розглядається як моральне поняття в контексті співвідношення моралі і права. Особливу увагу приділено вивченню добросовісності як оціночного поняття, яке необхідно розглядати з об'єктивної і суб'єктивної точок зору. Добросовісність у статті розглядається також як основоположне начало украӥнського права, правовий принци, правова аксіома, універсальне поняття і основоположна ідея права в иілому.

Категорія «добросовісність» розглядається комплексно (як принцип, презумпиія $і$ відкрита норма), акцентується увага на уніфікованих міжнародних нормативно-правових актів. Відзначено різноманітні підходи до трактування поняття «добросовісність» у різних правових системах.

Встановлення принципу добросовісності як загального принципу ицвільного права створило передумови для кращого захисту конституиійних иінностей у договірних відносинах.

Ключові слова: моральність, принцип добросовісності, основні права, принципи права, добросовісність, добросовісна поведінка.

Постановка проблеми. Актуальність дослідження цієї теми полягає у сучасних тенденціях країн Свропи до інтеграції, які потребують створення універсальних норм регулювання цивільних відносин. Сучасне українське цивільне право характеризується широким відображенням гуманістичних цінностей. Зокрема, про його прагнення до гуманізації, про спробу його осмислення в «іншому вимірі» свідчить і поява в законодавстві норм, в яких містяться посилання на морально-правові категорії.

Мета статті - розглянути категорію «добросовісність» із об'єктивної та суб'єктивної точки зору, як моральне поняття в контексті співвідношення моралі і права; висвітлити підходи до трактування
| поняття «добросовісність» у різних правових системах.

Виклад основного матеріалу. Враховуючи багатовіковий досвід нормотворення, варто зазначити, що вдосконалення цивільного законодавства відбувається не тому, що суб'єкти правовідносин не мають чітких настанов до дії, а тому що виникають нові відносини, які не мають відповідного «шаблону» в законі. Цей «шаблон» являє собою конкретну норму, яка створює певні правила, адаптовані до реальних суспільних відносин. У цивілістиці, де значна частина відносин врегульовується диспозитивним шляхом, у зв'язку з динамічним розвитком життєвих ситуацій, законодавець не може, та й немає в цьому практичної необхідності, 
встигати створювати норми, які б урегульовували нові відносини.

Узв'язкузцимважливопам'ятати,щобудьякі відносини між учасниками цивільного обороту із самого початку не можуть перебувати в чітко визначених правових межах. Такою всеосяжною функцією наділяються норми-принципи: саме вони, згідно з механізмом дії аналогії права, $є$ кінцевим орієнтиром усіх учасників цивільних правовідносин. Більш того, принципи цивільного права були і продовжують залишатися критеріями правильного розуміння того, яким вимогам має відповідати зміст галузевого регулювання, а звідси і формалізована поведінка його учасників.

На сучасному етапі розвитку права в цілому і цивільного права зокрема спостерігається тенденція до моралізації, що виявляється в розгляді правових явищ крізь призму моральних категорій. Цивільне право розвивається в напрямі наближення позитивного законодавства до природно-правової ідеології. Принципи цивільного права завжди виступали як традиційний метод і засіб правового впливу на суспільні відносини, що становлять предмет цивільного права.

Категорія добросовісності викликає безліч суперечок у науковій літературі. Одні вчені вважають, що добросовісність є принципом цивільного права, інші спростовують дану позицію. Одні розглядають їі як межу здійснення прав, інші доводять неспроможність цієї теорії.

Як зазначає С. В. Богданов, даний принцип насамперед спрямований на зміцнення моральних начал цивільно-правового регулювання [1, с. 30-31]. На думку Л. В. Щенникова, принцип добросовісності повинен виступити провідником ідеї виховання в людях якостей правдивості, шанобливості, наполегливості, ввічливості, доброти [2, с. 12]. На думку М. Г. Єлісєєва, поведінка $є$ сумлінною тією мірою, якою вона визначається добром; у добросовісній поведінці вирішальним $є$ не тільки зовнішній вчинок, але і його мотиви, моральна оцінка його прогнозованих результатів [3, с. 11].

Як зазначає І. Б. Новицький, «добра совість включає в себе такі елементи, як: знання про інше, про його інтереси; знання, пов'язане з відомою доброзичливістю; елемент довіри, впевненість, що моральні основи обороту беруться до уваги, що від них виходить кожен в своїй поведінці» [4, с. 65]. Добра совість в першому і найповнішому розумінні є принципом вірності договору, поваги до договору, дотримання даного слова. Ця позиція близька до розуміння «bona fides» у римському праві, яка розгля- далася як «власна чесність і довіра до чужої чесності, вірність даному слову, моральний обов'язок всіх людей $<\ldots>$ виконувати свій обов'язок, у чому б він не виражався».

У такого трактування доброї совісті $€$ опоненти. Так, наприклад, Л. І. Петражицький вважав, що поняття «bona fides» «не містить у собі ніякого морального ключа», «не ототожнюється 3 чесністю або будь-якими моральними заслугами», це $€$ незнання [5, с. 195]. На думку О. О. Малиновського, добросовісність - це внутрішня межа здійснення права, яку слід розглядати як прагнення суб'єкта відмовитися від шкідливого здійснення права, виходячи зі своїх внутрішніх переконань, а моральність - це межа здійснення суб'єктивного права, яка вказує на встановлені суспільством межі дозволеного і забороненого [6, с. 26].

Дещо іншої точки зору дотримується В. Н. Бабаєв, розрізняючи поняття доброчесності та сумлінності. Причому сумлінність розглядається тільки як характеристика виконання обов'язків. «Доброчесність - це поведінка людини, що характеризується дотриманням тих правил, норм, умов життя, принципів, які вважаються позитивними. $<\ldots>$ У праві добропорядним може бути визнано таку поведінку суб'єкта, яка не суперечить приписам правових норм, визнається корисною, потрібною <...> сумлінність слід розуміти як чесне, з усією ретельністю і акуратністю виконання обов'язків, старанність, ретельність» [7, с. 87].

Найбільш категорична в питанні про моральний складник принципу добросовісності О. Є. Богданова, яка стверджує, що категорія «сумлінність» лежить виключно в морально-етичній сфері і може бути пояснена тільки за допомогою оціночної категорії «моральність»; що поведінка учасників цивільного обороту, що відображає уявлення суспільства про добро, слід вважати моральною i, отже, сумлінною, а поведінка, що відбиває уявлення про зло, навпаки, аморальною і недобросовісною [8, с. 15].

Отже, згідно з найбільш поширеною думкою, категорія добросовісності визначається через етичні, моральні категорії. Водночас включення в категорію сумлінності так званого об'єктивного критерію незнання певних фактів дозволяє говорити про іiі нетотожність категорії моральності. Другий підхід до визначення змісту категорії сумлінності в цивільному праві полягає якраз в її розгляді з позиції об'єктивних критеріїв, які пов'язані з мораллю, моральністю. Третій - відносить сумлінність до принципів права.

Провівши аналіз перерахованих точок зору, констатуємо, що як будь-яка моральна 
категорія, закріплена в нормах права, сумлінність може характеризуватися з об'єктивного і суб'єктивного боку. Об'єктивний характер їй надає закріпленість у нормах права, суб'єктивний - сприйняття норм права через внутрішні уявлення самого суб'єкта про добро і совість. Добросовісність є співвідношенням зважених індивідуальних інтересів 3 приватними інтересами інших осіб і суспільства в цілому.

Сучасне цивільне законодавство базується на римському праві. Це простежується як у загальних положеннях і принципах права, так і в окремих інститутах речового, зобов'язального, спадкового права.

Чинний Цивільний кодекс, який було прийнято в 2003 р., закріплює і розвиває необхідні гарантії і основні принципи приватного права. Це принципи рівності громадян перед законом (aequitas), справедливості (iustitia), добросовісності (bona fidei), свободи волі учасників цивільних відносин (libertas voluntatis hominis).

Вплив римського приватного права на сучасне цивільне законодавство настільки великий, що його неможливо звести до якоїсь певної кількості статей Цивільного кодексу України. Випадки прямого або опосередкованого впливу римського права численні. Це стосується як загальних положень права, так і статусу осіб, позовної давності, речових та зобов'язальних прав, окремих видів договорів, спадкового права тощо.

Включення окремих оціночних категорій у текст законів здійснюється в рамках загальної моралізації українського законодавства. Ступінь взаємодії права і моралі під час застосування норм різних галузей права неоднаковий. Це пов'язано з тим, що неоднорідні дії і суспільні відносини вимагають різних способів і методів регулювання: до одних підходять методи правового, до інших - морального регулювання, треті піддаються як тому, так і іншому способу опосередкування, четверті можуть не входити ні у сферу правового, ні у сферу морального регулювання. Люди здійснюють ряд дій, які лежать у сфері правового регулювання, але є морально індиферентними. До них, наприклад, належать дії, регульовані техніко-юридичними нормами.

Об’єктивною передумовою закріплення оціночних категорій у цивільному законодавстві є необхідність відображення явищ морального та етичного характерів. Цивільне право і мораль мають певні точки дотику. Оновлене цивільне законодавство зуміло втілити новий дух, який Л. В. Щенникова позначила «духом моральності».

Моральні норми є першоосновою буття права і його складовою частиною, а тому названі як загальні начала, вони є визначальними у регулюванні цивільних відносин. Чинний цивільний кодекс України (ст. 3), закріплюючи загальні засади цивільного законодавства, не розмежовує правові та моральні принципи, поставивши їх в один ряд.

Відповідно до ст. 11 Цивільного кодексу України, «цивільні права та обов'язки виникають із дій осіб, що передбачені актами цивільного законодавства, а також із дій осіб, що не передбачені цими актами, але за аналогією породжують цивільні права та обов'язки». Відповідно, у разі вчинення дій, які не врегульовані нормами цивільного законодавства, перед судом може постати завдання оцінки таких дій.

Виходячи 3 формулювання ст. 11 ЦК України, можна зробити висновок, що такі дії повинні відповідати загальним засадам цивільного законодавства України, які закріплені в ст. 3 ЦК України.

Багато вимог моралі закріплені в законодавстві, але механізми їх реалізації не працюють в нинішніх нестабільних у політичному, економічному та моральному сенсі умовах функціонування суспільства. Суть проблеми полягає в тому, щоб наповнити реальним змістом декларовані в законах норми і співвідносити їх із тими процесами, які відбуваються в суспільстві.

Слід зазначити, що не лише Український цивільний кодекс містить принцип добросовісності. У цивільних правових системах держав світу науковці говорять про дві форми прояву принципу добросовісності. Перша з них - суб'єктивна, відповідно до якої сторони повинні діяти у відносинах один з одним чесно і справедливо. Інша - об'єктивна - висуває добросовісність як вимогу дотримання сторонами розумних стандартів чесності в договірних відносинах.

Відповідно до німецького законодавства договірні зобов'язання підпорядковуються принципу добросовісності, конкретний зміст якого виводиться шляхом доктринального і судового тлумачення 3 вельми скромного $\S 242$ Німецького цивільного уложення, безпосередньо стосується способу виконання договірних зобов'язань: боржник зобов'язаний виконати зобов'язання добросовісно з урахуванням звичаїв цивільного обороту. Крім того, було досягнуто консенсусу щодо цілої низки випадків застосування принципу добросовісності: під час переговорів при укладенні договору, виконання договору, neminem laedere (внаслідок загальної деліктної недбалості) і ін.

На доктринальному рівні виділяються два підходи до розуміння добросовісності: 


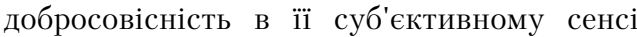
(Guter Glauben) і в об'єктивному (Treu und Glauben), що загалом характерно для німецької цивілістики і цілком відповідає підходам до розуміння добросовісності в римському праві.

у тексті Французького цивільного кодексу лише двічі вказується на добросовісність: у п. 4 ст. 1134 («угоди повинні бути виконані сумлінно») і ст. 1135 («угоди зобов'язують не тільки до того, що в них виражено, але і до всіх наслідків, які справедливість, звичай або закон пов'язують із цим зобов'язанням, відповідно до його природи»), проте в теорії вона отримала досить широку розробку. Інших явних посилань на принцип добросовісності розділ цивільного кодексу Франції про зобов'язання не містить. Проте починаючи 3 кінця 70-х років французька доктрина розширила перелік ситуацій застосування принципу добросовісності, поширивши його на переговорні відносини та виконання договору, передбачаючи принаймні два аспекти застосування: обов'язок взаємодії і обов'язок лояльності.

Обов'язок взаємодії сторін проявляється в двох аспектах: висновок максимально вигідних договорів і надання повної інформації під час укладання договору.

Обов'язок лояльності також має два аспекти: використання належних засобів (сторони повинні діяти спільно для досягнення загальних цілей, зазначених у договорі, і уникати створення для своїх контрагентів труднощів, яких можна було б уникнути) i досягнення результату (сторони під час укладення та виконання договору повинні діяти 3 ретельністю і належною обачністю, властивою «батькові сімейства») [9].

Але навіть і посилена доктриною французька bonne foi досі ослаблена судовим розсудом у визначенні справедливості та добросовісності, створюючи, незважаючи на традиційно позитивний характер французького права, ризик занадто широкого суддівського розсуду.

Загалом французька правова традиція розглядає доктрину добросовісності як підставу для обмеження свободи договору і не знає властивого німецькому праву поділу сумлінності на об'єктивну і суб'єктивну, однак, як і німецьке право, має доктринально закріплений принцип добросовісності і розуміє її як вид відкритої норми, хоча і прагне до обмеження її застосування.

у Сполучених Штатах цей принцип закріплений в Єдиному комерційному кодексі, який передбачає, що «кожен договір або зобов'язання відповідно до цього Кодексу встановлює обов'язок добросовіс- ності при його виконанні або дотриманні» (§ 1-304 СКК).

Сучасне право Сполученого Королівства ніколи не мало загальної норми, схожої на ст. 242 ГГУ, з якої можна було б вивести обов'язок діяти добросовісно. Англійське право традиційно не визнає обов'язок добросовісності виконання своїх зобов'язань сторонами. Це положення ілюструється таким коментарем: «відповідно до принципів свободи та обов'язкової сили договору в англійському договірному праві немає правового принципу добросовісності загального застосування, хоча деякі автори стверджують необхідність його існування» [10, с. 32].

Водночас у праві Англії з XVIII століття діє принцип найвищої добросовісності (uberrimae fidei), що застосовувався лише до договорів страхування.

Але необхідно відзначити, що англійське право ставиться до загальних принципів права з певним презирством. Так, англійська доктрина і судова практика заперечували принцип сумлінності в його континентальній формі.

Отже, можна зробити висновок, що в англійському праві відсутній загальний обов'язок добросовісності, що випливає 3 договору. Водночас згідно з англійським правом обов'язок добросовісності покладається на сторони фідуціарних відносин. Однак, як правило, англійські суди не будуть передбачати в комерційному договорі обов'язок добросовісності.

Так, у рішенні у справі Yam Seng v. International Trade Corporation після детального аналізу суддя постановив, що договірні зобов'язання діяти добросовісно може трактуватися як обов'язок виконання договору в дусі доброї волі і прямо залежить від контексту договору [11]. Суддя визнав наявність в англійському праві обов'язку добросовісності, що розуміється не як питання права, але як питання факту, що означає, що вона заснована на передбачуваних намірах сторін. Таким чином, це питання побудови контракту, і вирішується в кожному конкретному випадку.

Проте право Великобританії сприйняло ідею сумлінності із середньовічного канонічного права - суду лорда Канцлера [12, с. 158]. Однак у процесі прийняття судового закону 1873 року більшість суддів визнали, що доктрина добросовісності є занадто складною для розуміння i, отже, для її подальшого формального закріплення.

Натепер англійське право часом застосовує негативні заходи до осіб, що діють недобросовісно, проте не визнає добросовісність як вид відкритої норми, яка застосовується 
до окремої категорії ситуацій, вважаючи за краще розбиратися в кожному конкретному випадку окремо. На доктринальному рівні ведуться дискусії про те, чи слід ввести добросовісність як загальне застосування норм. Однак уже тривалий час англійськими юристами висловлюється думка, що спільний обов'язок добросовісності буде введений в англійське право в результаті наближення до принципів договірного права в рамках Європейського союзу [13].

Категорія «добросовісність» закріплена в документах міжнародної уніфікації права: добросовісність здійснення прав і виконання обов'язків проголошується принципом міжнародного договірного права. Однак осмислення принципу добросовісності в міжнародному праві не зводиться до його розуміння в будь-якій країні. Як зазначається в літературі, принцип добросовісності отримав у міжнародному праві провідне значення завдяки формулюванням умов торгових договорів і судовій практиці.

Яскравим прикладом є справа «Norsolor v. Pabalk» [14], де суд посилався на принцип добросовісності як основний при укладанні і виконанні договору, що сприяє «оптимізації» (відродженню) міжнародного lex mercatoria.

у Принципах Сентрал, УНІдРУА і ПЄДП (далі - Принципи) встановлюється обов'язок кожної сторони діяти відповідно до принципу добросовісності, причому такий обов'язок не може бути виключено або обмежено. Як зауважив О. С. Комаров, добросовісність розглядається як одна 3 основних ідей, закладених у Принципах: даний принцип не обмежується порядком виконання зобов'язань, а застосовується також до різних форм зловживання правом - non concedit venire contra factum proprium; заборона вимоги того, що було раніше відкликано (dolo agit qui petit quod redditurus est), а також заборона дій сторони, несумісних із певним розумінням, яке виникло 3 незалежних від неї причин в іншої сторони і т. д. $[15$, c. 20$]$.

\section{Висновки}

Отже, як висновок можна констатувати той факт, що правові традиції держав світу в цілому визнають принцип добросовісності, який передбачає, що сторони повинні діяти добросовісно під час виконання своїх зобов'язань за договором. Більшість правових систем цивільного права визнають ту або іншу форму обов'язку сторін договору виконувати свої зобов'язання добросовісно, хоча фактичний зміст цього обов'язку відрізняється в різних країнах.
Звісно ж, західна цивілістична наука досягла більшого успіху у дослідженні даного правового феномена, в тому числі і тому, що не боялася міркувати про моральність у праві. Введення в цивільне законодавство принципу добросовісності як одного з найбільш загальних і важливих принципів цивільного права $€$ заходом, спрямованим на зміцнення моральних засад цивільно-правового регулювання. Саме з позиції моральності слід підходити до оцінки поведінки суб'єкта права як добросовісного або недобросовісного.

\section{Список використаних джерел:}

1. Богданов Е. В. Гражданское право России как регулятор экономических отношений. Законодательство и экономика. 2012. № 1. С. 29-36.

2. Щенникова Л. В. Идеология гражданского законодательства. Законодательство. 2010. № 4. C. 10-13.

3. Елисеев Н. Г. Добросовестность и разумность в правовом поведении. Законы России: опыт, анализ, практика. 2010. № 9. С. 10-14.

4. Новицкий И. Б. Принцип доброй совести в проекте обязательственного права. Вестник Гражданского права. 1916. № 6 (Октябрь). С. 56-90. С. 65.

5. Петражицкий Л. Права добросовестного владельца на доходы с точек зрения догмы и политики гражданского права. 2-е изд., доп. и испр. С.-Пб.: Тип. Ю. Н. Эрлих, 1902. С. 195.

6. Малиновский А. А. Нравственность в гражданском праве. Нотариус. 2007. № 5. С. 26.

7. Бабаев В. Н. Презумпции в советском праве. Горький: Изд-во ГВШ МВД СССР, 1974. С. 87.

8. Богданова Е. Е. Принцип добросовестности и судебное усмотрение. Законы России: опьы, анализ, практика. 2012. № 1. С. 15.

9. Picod Y. L'obligation de coopération dans l'exécution du contract, JCP 1988, I, 3318; terré f, simler r., laquette y., Droit Civil - Les obligations, 6e éd. Paris, 1996. P. 350, 416; Ghestin J. La formation du contrat, 3e éd. Paris, 1993. P. 232.

10. Chitty on Contracts $31^{\text {st }}$ ed.: Volume 1 General Principles. Para. 1-039. P. 32.

11. Yam Seng PTE Ltd v. International Trade Corporation Ltd [2013] EWHC 111 (QB) (01 February 2013)

12. Baker J. An Introduction to English Legal History (3rd ed, 1990), at 123. Cf W T Barbour, 'The History of Contract in Early English Equity' in Paul Vinogradoff (ed), Oxford Studies in Social and Lega 1 History (1914). Vol. 4, at 158.

13. Towards an Implied Duty of Good Faith Under English Law. Jones Day Commentary. URL : http://www.jonesday.com/flles/Publication (дата звернення: 03.03.2020).

14. Norsolor v. Pabalk // Rev.arb. 1983. P. 525 ff. - France / 09 October 1984 / France, Cour de cassation / Société Pabalk Ticaret Limited Sirketi c. Société Norsolor / 83-11.355/

15. Принципы международных коммерческих договоров УНИДРУА 2004 г. / gep. с англ. А. С. Комарова. Москва, 2006. С. 20. 
The article is dedicated to the research of the main expressions of the principle of good faith in civil law and private international law. The relevance of the study is determined, in particular by the acute need for a legal definition of the principles of good faith in the Civil Code. The interest in the scientific and practical study of these principles in civil law is caused by a variety of reasons, and in particular by the fact that the legislator does not disclose the content of these principles in the Civil Code. European theory has not graphs, that describe and characterize the specifics in applying the principles good faith have been published.

In the course of the work, a comparative analysis of the principles of conscientiousness in Ancient Rome and their current state, revealing general and special characteristics was carried out. We can talk about the similarity of concepts, but also about their different interpretations.

The role of the principle of good faith in the legal order is treated through the functions and values. When the principle of good faith is applied, its content has to be specified in accordance with the constitutional values, the values of ordinary laws and the standards of collective value beliefs.

Principles of law determine the General orientation, high quality and effectiveness of law-making and prorealtime practice in any civilized society. That is why there are such a great importance has an objective and comprehensive study of this phenomenon, both on the General theoretical and sectoral level of jurisprudence.

For the sake of the research objectives, good faith is regarded as a moral concept in the context of interrelation between morality and law. Special attention is paid to the study of good faith as an evaluative concept that needs to be considered from objective and subjective sides. Also, good faith is scrutinized as one of the foundations of law in the Ukraine, a legal principle, legal axiom, universal concept and the basic idea of the Law.

The category of «good faith» is considered in a comprehensive manner (as a principle, presumption and open rule) based on unified international legal acts. There is a variety of interpretations of the concept of «good faith» in different legal systems.

Establishment of the principle of good faith as a general principle of civil law has created preconditions fora better protection of constitutional values in contractual relationships.

Key words: morality, principle of good faith, fundamental rights, principles of law, bona fides, integrity of behavior. 